\title{
Presence of a Gonadotropin Inhibiting Substance in the Urine of Albino Rats
}

\author{
Minoru OTA, K. S. HSIEH AND KiJuro OBARA \\ Department of Biochemistry, Iwate Medical University \\ School of Medicine, Morioka, Iwate
}

\section{Synopsis}

\begin{abstract}
The presence of a luteinizing hormone inhibitor in the urine of albino rats was demonstrated. This inhibitor is a heat-stable, non-dialyzable, acid-precipitable and celiteabsorptive substance.
\end{abstract}

The presence of the luteinizing hormone (LH) inhibitor was reported in human urine (Soffer et al., 1961, 1962, Dronkert et al., 1963, Ota et al., 1968a, b). This inhibitor, which is concentrated by processing urine as for gonadotropins, is heat-stable, unlike the gonadotropins present. The follicle stimulating hormone (FSH) inhibitor, which is labile to heat, was shown in the urine of the Bonnet Monke (Sairam et al., 1966, 1968).

The present paper describes the presence of a $\mathrm{LH}$ inhibitor in the urine of albino rats.

\section{Methods}

Male albino rats of the Wistar strain, aged 9 to 16 weeks, were kept in cages designed specially for collection of urine. The animals were exposed to a $14 \mathrm{hr}-$ lighting and a $10 \mathrm{hr}$-darkness schedule of artifical illumination, lights on at 5:30 and off at 19:30. Twenty-four hr urine specimens were collected using toluene as a preservative and brought into a refrigerator twice a day. Pooled urine was extracted according to the tannic acid precipitation method of Johnsen (1958) and the residue was washed with alcohol twice and with ether once. The residue was, then, dissolved in a $0.1 \mathrm{M}$ sodium borate buffer solution $(\mathrm{pH} 8.6)$ and was stood overnight in a refrigerator. The extract was centrifuged at $1,500 \mathrm{rpm}$ for $15 \mathrm{~min}$ and the supernatant was heated in a boiling water bath for one hour to destroy the activity of pituitary gonadotropins.

A portion of urine was acidified to $\mathrm{pH} 3.8-4.0$ with glacial acetic acid and stored at $5^{\circ} \mathrm{C}$ for 2 days. The precipitate which was developed in the acidified

Received for publication October 1, 1970. urine was removed by centrifugation. The precipitate was washed with acetic water $(\mathrm{pH} 4.0)$ twice, with absolute alcohol twice and with ether once. The washed precipitate was extracted by a borate buffer solution according to Ota et al. (1967). The supernatant of the acidified urine was extracted according to Johnsen (1958), and the residue obtained was washed, dissolved and heated in the same procedures as those of the non-acidified urine.

Bio-assay The inhibitory effect of the extract of the non-acidified urine on FSH activity was estimated by the modified method of Brown (1955), and that on LH activity was studied by Parlow's ovarian ascorbic acid depletion method (1961) and the ovulation method of Ota et al. (1968a, b)

In Brown assay, 21-day-old female mice of the ICR-JCL strain were used. The heated extract of the non-acidified urine equivalent to 4 day-urine specimens was mixed with $100 \mu \mathrm{g}$ of NIH-FSH-S 3 and 12 i.u. of human chorionic gonadotropin (HCG, Gonatropin, Teikoku Zoki Co.) and injected twice daily for three days in a volume of $0.5 \mathrm{~m} l$ per injection. The animals were killed 16 hours after the final injection and the ovaries were weighed.

In the Parlow's assay, 25 to 26-day-old female rats of the Holtzman strain were used. The rats were injected subcutaneously with 50 i.u. of pregnant mare's serum gonadotropin (PMS, Serotropin, Teikoku Zoki Co.), followed with 50 i.u. of HCG being injected 56 hr later. Six days after the injection of HCG, 1, 4 and $8 \mu \mathrm{g}$ of NIH-LH-S 11 or $4 \mu \mathrm{g}$ of NIH-LH-S 11 with the heated extract of the non-acidified urine equivalent to 4 or 8 day urine specimens per $100 \mathrm{~g}$ of body weight was injected through the saphenous vein. Three hours later the ovaries were rapidly removed and weighed. The ascorbic acid content of the ovaries was determined by the Mindlin and Butler's method (1938).

In the ovulation method, 21-day-old female mice of the ICR-JCL strain were used. One i.u. of PMS was injected intraperitoneally at 2 p.m. as a priming 
dose, followed by 0.5 i.u. of HCG at 2 p.m. on the third day at an interval of $48 \mathrm{hr}$ as an ovulatory dose. The ovulated eggs in the oviducts were counted under a microscopy $18 \mathrm{hr}$ after the injection of HCG. 7 to 13 ova were usually found in both oviducts. The heated urine extract obtained from 2-8 day-urine specimens, when given, was mixed with HCG prior to the injection. The absence or suppression of ovulation was considered as the evidence for the presence of GIS.

The inhibitory effect of the extract obtained from the precipitate or the heated extract of the supernatant of the acidified urine, each equivalent to 4 day-urine specimens per mouse, on the ovulation induced with 1 i.u. of PMS and 0.5 i.u. of HCG was studied.

\section{Result}

The average urine volume of 24 -hr period per rat was about $9 \mathrm{ml}$. As shown in Table 1, no inhibitory effect of the heated extract obtained from the non-acidified urine of rats on

Table 1. Effect of the heated extract of rat urine on the FSH activity assayed in mice

\begin{tabular}{|c|c|c|c|c|c|}
\hline Treatment & $\begin{array}{l}\text { No. of } \\
\text { mice }\end{array}$ & $\begin{array}{c}\text { Initial } \\
\text { body wt.(g) } \\
\text { Av. } \pm \text { S.E. }\end{array}$ & $\begin{array}{c}\text { Final } \\
\text { body wt.(g) } \\
\text { Av. } \pm \text { S.E. }\end{array}$ & $\begin{array}{c}\text { Ovarian } \\
\text { wt. (mg) } \\
\text { Av. } \pm \text { S.E. }\end{array}$ & $\begin{array}{c}\text { Uterine } \\
\text { wt. (mg) } \\
\text { Av. } \pm \text { S.E. }\end{array}$ \\
\hline- & 6 & $13.1 \pm 0.4$ & $16.4 \pm 0.4$ & $8.7 \pm 0.8$ & $37.5 \pm 1.5$ \\
\hline FSH $100 \mu \mathrm{g}$ & 6 & $13.1 \pm 0.2$ & $16.4 \pm 0.3$ & $10.2 \pm 0.4 *$ & $42.6 \pm 1.1$ \\
\hline FSH $100 \mu \mathrm{g}+$ & 6 & $13.1 \pm 0.3$ & $16.3 \pm 0.4$ & $10.9 \pm 0.5$ & $49.8 \pm 1.6$ \\
\hline $\begin{array}{l}\text { FSH } 100 \mu \mathrm{g}+ \\
\text { extract (4 days' urine eq.) }\end{array}$ & 6 & $13.1 \pm 0.4$ & $16.2 \pm 0.5$ & $12.0 \pm 1.3^{*}$ & $46.1 \pm 0.5$ \\
\hline- & 6 & $14.1 \pm 0.5$ & $16.4 \pm 0.4$ & $8.0 \pm 0.6$ & $40.5 \pm 2.8$ \\
\hline FSH $200 \mu \mathrm{g}$ & 6 & $14.1 \pm 0.4$ & $17.4 \pm 0.3$ & $10.0 \pm 1.0 \dagger$ & $53.4 \pm 3.4$ \\
\hline $\begin{array}{l}\text { FSH } 200 \mu \mathrm{g}+ \\
\text { extract ( } 4 \text { days' urine eq.) }\end{array}$ & 6 & $14.1 \pm 0.6$ & $17.3 \pm 0.8$ & $11.7 \pm 1.4 \dagger$ & $50.5 \pm 2.5$ \\
\hline $\begin{array}{l}\text { FSH } 200 \mu \mathrm{g}+ \\
\text { extract ( } 8 \text { days' urine eq. })\end{array}$ & 6 & $14.1 \pm 0.6$ & $17.2 \pm 0.4$ & $12.9 \pm 1.5 \dagger$ & $55.6 \pm 4.2$ \\
\hline
\end{tabular}

$*$ and $\dagger$ These groups do not differ significantly.

Table 2. Effect of the heated extract of rat urine on the ovarian ascorbic acid depletion induced by $\mathrm{LH}$ in rats

\begin{tabular}{lccc}
\hline \hline Treatment & $\begin{array}{c}\text { No. of } \\
\text { rats }\end{array}$ & $\begin{array}{c}\text { Ovarian ascorbic acid } \\
\text { (mg/100 ovary) } \\
\text { Av. } \pm \text { S.E. }\end{array}$ & $\begin{array}{c}\text { Depletion percent } \\
\%\end{array}$ \\
\hline LH $1 \mu \mathrm{g}$ & 6 & $66.9 \pm 2.3$ & 100 \\
LH $4 \mu \mathrm{g}$ & 6 & $53.3 \pm 1.1^{*}$ & 79.6 \\
LH $8 \mu \mathrm{g}$ & 6 & $45.9 \pm 2.2$ & 68.6 \\
LH $4 \mu \mathrm{g}+$ extract & 6 & $53.9 \pm 2.1^{*}$ & 80.5 \\
(4 days' urine eq.) & & $55.0 \pm 1.5^{*}$ & 82.2 \\
LH $4 \mu \mathrm{g}+$ extract & 6 & $63.7 \pm 3.6$ & 100 \\
(8 days' urine eq.) & & $51.6 \pm 5.4 \dagger$ & 81.0 \\
\hline $\begin{array}{l}\text { LH } 1 \mu \mathrm{g} \\
\text { LH } 4 \mu \mathrm{g}\end{array}$ & 6 & $55.1 \pm 5.1 \dagger$ & 86.5 \\
$\begin{array}{l}\text { LH } 4 \mu \mathrm{g}+\text { extract } \\
\text { (4 days' urine eq.) }\end{array}$ & 6 & $57.0 \pm 5.6 \dagger$ & 89.6 \\
$\begin{array}{l}\text { LH } 4 \mu \mathrm{g}+\text { extract } \\
\text { (8 days' urine eq.) }\end{array}$ & 6 & & \\
\hline
\end{tabular}

$*$ and + These groups do not differ significantly. 
the FSH activity in mice was observed. The effect of the heated urinary extract of the nonacidified urine on the ovarian ascorbic acid depletion induced by $\mathrm{LH}$ is shown in Table 2 . The ascorbic acid depleting effect of $\mathrm{LH}$ was somewhat inhibited by the heated urinary extract, although the difference was not significant. The inhibitory effects of the heated extracts of non-acidified urine of rats on the ovulation induced by PMS and HCG are shown in Table 3. The inhibitory effect of the heated extract, which was obtained from the non-acidified urine or the extract of the supernatant of the acidified urine, or the extract of the precipitate of the acidified urine was shown in Table 4. A marked inhibition on the ovula- tion was observed when the heated extract of the non-acidified urine or the extract obtained from the precipitate of the acidified urine was given with HCG.

A less increase of the body weight of the rats administered urinary extract presumably indicates the presence of toxic materials in the extract.

\section{Discussion}

The observations obtained in the ovulation method suggest that the heated extract of the non-acidified urine of albino rats has an inhibitory effect on LH. The findings obtained

Table 3. Effect of the heated extract of rat urine on the ovulation induced with PMS and HCG in mice

\begin{tabular}{lcccccc}
\hline Treatment & $\begin{array}{c}\text { No. of } \\
\text { mice }\end{array}$ & $\begin{array}{c}\text { Initial } \\
\text { body wt.(g) } \\
\text { Av. } \pm \text { S.E. }\end{array}$ & $\begin{array}{c}\text { Final } \\
\text { body wt.(g) } \\
\text { Av. } \pm \text { S.E. }\end{array}$ & $\begin{array}{c}\text { No. of } \\
\text { ovulated } \\
\text { mice }\end{array}$ & $\begin{array}{c}\text { Percentage } \\
\text { of ovulated } \\
\text { mice \% }\end{array}$ & $\begin{array}{c}\text { Ova per } \\
\text { mouse } \\
\text { Av. } \pm \text { S.E. }\end{array}$ \\
\hline $\begin{array}{l}\text { Control } \\
\begin{array}{l}\text { Extract equivalent to } \\
\text { 2 days' urine }\end{array}\end{array}$ & 12 & $13.2 \pm 0.4$ & $16.7 \pm 0.7$ & 12 & 100 & $11.2 \pm 0.8^{*}$ \\
$\begin{array}{l}\text { Extract equivalent to } \\
\text { 4 days' urine }\end{array}$ & 12 & $13.2 \pm 0.4$ & $14.1 \pm 0.4$ & 11 & 91.7 & $8.2 \pm 0.7^{*}$ \\
$\begin{array}{l}\text { Extract equivalent to } \\
\text { ( days' urine }\end{array}$ & 12 & $13.3 \pm 0.3$ & $14.1 \pm 0.5$ & 2 & 16.7 & $0.6^{*}$ \\
$\begin{array}{l}\text { Extract equivalent to } \\
\text { 8 days' urine }\end{array}$ & 12 & $13.2 \pm 0.6$ & $13.7 \pm 0.5$ & 0 & 0 & 0 \\
\hline
\end{tabular}

* These groups differ significantly $(\mathrm{P}<0.001)$

Table 4. Effect of the extract obtained from the supernatant or precipitate of the acidified rat urine on the ovulation induced with PMS and HCG in mice

\begin{tabular}{|c|c|c|c|c|c|c|}
\hline Treatment & $\begin{array}{l}\text { No. of } \\
\text { mice }\end{array}$ & $\begin{array}{c}\text { Initial } \\
\text { body wt.(g) } \\
\text { Av. } \pm \text { S.E. }\end{array}$ & $\begin{array}{c}\text { Final } \\
\text { body wt.(g) } \\
\text { Av. } \pm \text { S.E. }\end{array}$ & $\begin{array}{l}\text { No. of } \\
\text { ovulation } \\
\text { mice }\end{array}$ & $\begin{array}{c}\text { Percentage } \\
\text { of ovulated } \\
\text { mice } \%\end{array}$ & $\begin{array}{c}\text { Ova per } \\
\text { mouse } \\
\text { Av. } \pm \text { S.E. }\end{array}$ \\
\hline Control & 12 & $13.9 \pm 0.5$ & $17.2 \pm 0.7$ & 12 & 100 & $12.3 \pm 0.6 \dagger$ \\
\hline $\begin{array}{l}\text { Heated extract of non- } \\
\text { acidified urine* }\end{array}$ & 12 & $13.6 \pm 0.4$ & $14.3 \pm 0.3$ & 1 & 8.3 & 0.3 \\
\hline $\begin{array}{l}\text { Heated extract of super- } \\
\text { natant of acidified urine* }\end{array}$ & 11 & $13.6 \pm 0.5$ & $15.8 \pm 0.6$ & 11 & 100 & $10.5 \pm 0.6 \dagger$ \\
\hline $\begin{array}{l}\text { Extract of precipitate of } \\
\text { acidified urine* }\end{array}$ & 11 & $13.7 \pm 0.3$ & $15.3 \pm 0.8$ & 0 & 0 & 0 \\
\hline
\end{tabular}

* Each extract was equivalent to 4 day-urine.

$\dagger$ These groups do not differ significantly. 
in the ovarian augmentation assay indicate that the urinary extract has no inhibitory effect on the FSH activity. In fact, even an enhancement of ovarian weight was observed in the mice receiving the extract with FSH. This might be due to the fact that biological activity of gonadotropin was not completely destroyed after heating for one hour at $100^{\circ} \mathrm{C}$ (Krishnamurti and Bell, 1967). On the other hand, the results of the ovarian ascorbic acid depletion assay suggest that the urinary extract has a tendency to suppress the $\mathrm{LH}$ activity, but a significance was not obtained. In our laboratory, a narrow variation of the ascorbic acid contents per $100 \mathrm{~g}$ of ovary in a certain experimental group has hardly been obtained. Even in the assay using the heated urinary extract of adult males, a definite inhibition on the ovarian ascorbic acid depletion was not constantly obtained due to wide variations of the contents in the control and experimental groups. Koed and Hamburger (1968) reported that the ovarian ascorbic acid depletion test is unreliable for the assay of LH in the extracts of human urine and Herbst et al. (1967) reported that relatively crude extracts of human urine tend to invalidate the assay. The ovarian ascorbic acid depletion test might not be also adequate for assay of GIS.

Soffer and his colleagues have measured GIS by its depressing effect on the uterine weight of immature mice treated with a small dose of HCG. However, this method has not been used in our laboratory, because this method seemed to be inadequate for detection of GIS.

In our laboratory, the ovulation method has been preferably employed for GIS assay. This method for $\mathrm{LH}$ and HCG depending on the induction of ovulation in immature mice was reported by Zarrow et al. (1958) and Cunningham (1962). Although it was later shown that this assay is not specific for $\mathrm{LH}$, ovulation response is paralleled with ovulating doses when a certain amount of PMS is injected as a priming dose and ovulation is suppressed when GIS is given with HCG. Consequently, it is proposed that the heated extract obtained from the urine of rats seemed to have an inhibitory effect mainly against the LH property of gonadotropins.

It was reported by Sairam et al. (1966) that there was only a gonadotropin-inhibiting substance in the urine of the Bonnet Monkey, Macaca radiata besides the substance in human urine. The inhibitor in monkeys is a heat-labile protein which suppresses the FSH property of gonadotropins, unlike the human one which is a heat-stable LH-inhibitor.

Although the presence of toxic materials, which caused death of the animals when a higher dosage was given, was observed, inhibition on the ovulation might not be due to toxicity, because there was no correlation between the inhibitory effect of the extract and the increasing rate of the body weight.

It was found that this inhibitor could be precipitated by acidification of urine and extracted with a borate buffer solution ( $\mathrm{pH} 8.6)$. The characteristic of this inhibitor is similar to that of the LH-inhibitor in the human urine in respect to its heat stability and non-dialyzability (In the extraction of the precipitate according to Ota et al. (1967), the extract obtained with a weak basic solution was dialyzed against running water overnight). This inhibitor is a celite-absorptive substance like that of the human urine, as indicated by the fact that it is absorbed by hyflo-supercel when it is processed according to Johnsen (1958).

\section{Acknowledgments}

This study was supported by a grant from the Population Council. NIH-FSH and LH were kindly supplied by the Endocrinology Study Section, NIH: Bethesda, Maryland, U.S.A. The authors are indebted to Miss Nobuko Sato for her technical assistance.

\section{References}

Brown, P. S. (1955). J. Endocrinol. 13, 59. Cunningham, F. J. (1962). Ibid. 24, 215. 
Dronkert, A., M. Ota and N. Purshottam (1963). Clin. Res. 12, 89. (abstract).

Herbst, A. L., E. T. Bell and J. A. Loraine (1967). Endocrinology 80, 378.

Johnsen, S. G. (1958). Acta Endocrinol. 28, 69.

Koed, H. J. and C. Hamburger (1968). Ibid. 59, 629.

Krishnamurti, M. and E. T. Bell (1967). J. Reprod. Fertil. 13, 149.

Mindlin, R. L. and A. M. Butler (1938). $J$. Biol. Chem. 122, 673.

Ota, M., A. Dronkert and A. H. Gates (1967). Endocrinol. Japan. 14, 284.

Ota, M., A. Dronkert and A. H. Gates (1968 a). Fert. Steril. 19, 100.
Ota, M., A. Dronkert and A. H. Gates (1968 b). Metabolism 17, 181.

Parlow, A. F. Human Pituitary Gonadotropins (edited by A Albert). Thomas, Springfield, Illinois, p. 300 (1958).

Sairam, M. R., H. G. Madhwa Raj and N. R. Moudgal (1966). Endocrinology 78, 923.

Sairam, M. R., H. G. Madhwa Raj and N. R. Moudgal (1968). J. Endocrinol. 40, 165.

Soffer, L. J., W. Futterweit and J. Salvaneschi (1961). J. Clin. Endocrinol. 21, 1267.

Soffer, L. J., J. Salvaneschi and W. Futterweit (1962). Ibid. 22, 532.

Zarrow, M. X., A. L. Caldwell, E. S. E. Hafez and G. Pincus (1958). Endocrinology 63, 748. 